the cytochrome $c_{2}$ isolated from the related photoheterotroph, Rhodospirillum rubrum ${ }^{2}$.

This research was supported by Grant GB 3908 from the National Science Foundation.

Department of Biology, Boston College,

Joseph A. OrLando

Chestnut Hill, Mass. (U.S.A.)

i M. D. Kamen, R. G. Bartsch, T. Horio and H. De Klerk, in S. P. Colowick and N. O.

KaPlan, Methods in Enzymology, Vol. VI, Academic Press, New York, 1963, p. 391.

2 T. Horio and M. D. Kamen, Biochim. Biophys. Acta, 48 (г96r) 266.

3 G. Cohen-Bazire, W. R. Sistrom and R. Y. Stanier, J. Cellular Physiol., 49 (i957) 25.

4 R. G. Bartsch, in H. Gest and A. San Pietro, Bacterial Photosynthesis, Antioch Press, Yellow Springs, Ohio, I963, p. 475.

5 D. Drabkin, J. Biol. Chem., I 46 (1942) 605.

6 D. Andrews, Biochem. J., 9I (I964) 222.

7 S. F. Velick and P. Strittmatter, J. Biol. Chem., 22 I (I956) 265.

Received June 23rd, I967

Biochim. Biophys. Acta, I 43 (1967) 634-636

BBA 43 I 74

\title{
Electron paramagnetic resonance studies on the cytochrome oxidase from yeast
}

The availability of preparations of purified mammalian cytochrome oxidase (cytochrome $c: \mathrm{O}_{2}$ oxidoreductase, EC I.9.3.I) has stimulated an extensive chemical and physical investigation of the properties of this complicated and extremely important terminal oxidase (a collection of articles which documents much of this work is to be found in ref. I). In addition to the two heme components, the enzyme also contains stoichiometric amounts of copper. EPR techniques have proved invaluable in documenting the presence, nature and functional role of the component ${ }^{2-4}$, although it is well established that EPR only accounts for about one-half of the chemically detectable copper present in the protein ${ }^{5}$.

Recently a highly purified preparation of cytochrome oxidase has been obtained from Saccharomyces cerevisiae ${ }^{6}$ and it is the purpose of this communication to report on the results that we have obtained by EPR spectroscopy of this preparation. As reported previously ${ }^{6}$, the preparations of cytochrome oxidase contain an average of $5.4,6.3,4.4$ and $5.8 \mathrm{~m} \mu$ moles of cytochromes $a+a_{3}$, copper, non-heme iron, and labile sulfide, respectively, per $\mathrm{mg}$ of protein and catalyze the oxidation of approx. $4^{0} \mu$ moles of ferrocytochrome $c$ per min per mg of protein. More recently, however, preparations of enzyme have been prepared by passage of the final preparations through a sucrose gradient with specific activities as high as 80 to 90 . Fig. IA is the EPR spectrum of the oxidase as prepared in the most highly purified form. It resembles markedly that exhibited by beef-heart cytochrome oxidase and is not at all typical of conventional 
copper complexes or other copper proteins in that (i) There is no indication of any of the unpaired electron-copper nucleus hyperfine interaction which generally splits the minor resonance at low field into four lines. (ii) The $g$ values are atypically low; $g_{1}=2.02$ and $g_{\|}=2.16$; these correspond closely to those found with the mammalian system, viz. 2.03 and 2.I7, respectively. These low values are usually interpreted as being due to a decrease in the orbital magnetism of the copper atom by delocalization of the unpaired electron to the ligands via convalent bonding ${ }^{7}$. (iii) The resonance is not easily saturated by microwave power-a phenomenon which is not yet understood. (iv) Double integration of the signal and comparison with a copper-EDTA standard indicated that the resonance corresponded to I.5 $\mathrm{m} \mu$ moles $\mathrm{Cu}$ per $\mathrm{mg}$ of protein. Direct chemical analysis revealed the presence of $6.8 \mathrm{~m} \mu$ moles $\mathrm{Cu}$ per mg of protein in the sample studied. The inability to account for all of the chemically detectable $\mathrm{Cu}$ in this enzyme by EPR techniques is well documented and has been the subject of a recent model study ${ }^{8}$. We have also observed the same EPR spectrum in electron transport particle prepared from yeast by the method of MACKLER ${ }^{9}$.

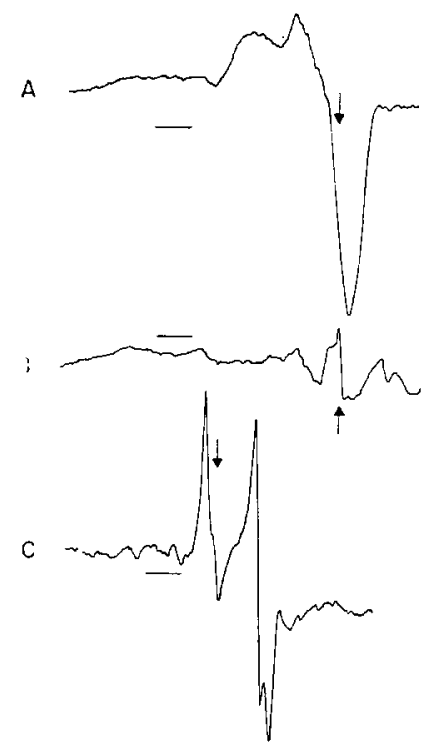

Fig. I. EPR spectrum of yeast cytochrome oxidase $(0.3 \mathrm{ml}, \mathrm{Ig} \mathrm{mg} / \mathrm{ml})$. A, before any additions; $\mathrm{B}, 30 \mathrm{sec}$ after additon of $5 \mu \mathrm{l}$ of $\mathrm{I} \%$ beef-heart cytochrome $c$ and $5 \mu 1$ of $\mathrm{O}$. I M sodium ascorbate; $\mathrm{C}, 30 \mathrm{sec}$ after addition of a few grains of solid dithionite. The spectra were obtained with a Varian $\mathrm{V}-4500$ EPR spectrometer operating at $9.227 \mathrm{GHz}$. The field modulation had a frequency of IoO $\mathrm{kHz}$ and an amplitude of $\mathrm{I} 2$ gauss. Microwave power was $27 \mathrm{~mW}$ and the temperature $63^{\circ} \mathrm{K}$. The magnetic field increases from left to right; the arrows indicate $g=2.00$ and the horizontal bars delimit roo gauss.

On addition of ascorbate and oxidised cytochrome $c$ to the protein the intensity of the main resonance is diminished by about $90 \%$ and a rather small background resonance is observed (Fig. IB). Neither ascorbate nor cytochrome $c$ alone had any effect under the same conditions. However, excess dithionite elicited the formation of an EPR signal characteristic of the non-heme iron proteins, with $g_{\mathbf{x}}=\mathbf{I} .9 \mathbf{I}$, $g_{\mathrm{y}}=\mathrm{I} .94$ and $g_{\mathrm{z}}=2.02$ (Fig. IC). A similar non-heme iron spectrum is also seen 
in yeast electron transport particle reduced with succinate, DPNH or dithionite.

We believe that this non-heme iron protein is not an integral component of yeast cytochrome oxidase, but is a component from higher up the electron transport chain, which fractionates with the cytochrome oxidase during purification. The failure of ascorbate and cytochrome $c$ (a reducing system which reduces both the heme and copper components of this enzyme) to reduce the iron would support this view.

Electron transport particle prepared ${ }^{10}$ from the respiratory deficient cytoplasmic mutant yeast $\mathrm{P}_{\rho}{ }^{-}$(ref. II) did not show any EPR signals typical of copper, although this mutant electron transport particle has a similar copper content to the normal yeast electron transport particle. This would suggest that in these mutants the copper is in a different form which could be either the diamagnetic $\mathrm{Cu}^{\mathrm{I}}$ species or a system of adjacent copper atoms interacting by either dipolar or exchange forces.

The demonstration that the copper components of both yeast and mammalian cytochrome oxidase is so similar is interesting in view of the observation that the enzyme from Pseudomonas aeruginosa completely lacks copper ${ }^{12}$. In view of the presence of at least one copper protein in this bacterium, it may be profitable to search for a second copper protein whose EPR characteristics resemble more closely the mammalian and yeast cytochrome oxidase.

This study was supported in part by Grant H-5457 and GM-I2 I76 from the National Institutes of Health. G.P. is a Recipient of the Career Development Award, GM-K $3-3 I_{2}$ I3 and B.M. of the Career Development Award, 2K3-HD-II28 from the National Institutes of Health. The authors wish to thank Standard Brands, Inc. for the generous supply of Fleischmann's yeast.

Biophysics Research Division, University of Michigan,

Graham Palmer

Ann Arbor, Mich., and

Bruce Mackler

Department of Pediatrics, University of Washington,

Seattle, Wash. (U.S.A.)

I T. E. King, H. S. Mason and M. Morrison, Oxidases and Related Redox Systems, John Wiley, New York, I965, p. 539-8I2.

2 H. Beinert, D. E. Griffiths, D. C. Wharton and R. H. Sands, J. Biol. Chem., 237 (ig62) 2337.

3 Q. H. Gibson and C. Greenwood, Biochem. J., 86 (I963) $54 \mathrm{I}$.

4 H. Beinert and G. Palmer, J. Biol. Chem., 239 (I964) i 22 I.

5 H. Beinert, in J. Peisach, P. Aisen and W. E. Blumberg, The Biochemistry of Copper, Academic Press, New York, I966, p. 2 I 3.

6 H. M. Duncan and B. Mackler, J. Biol. Chem., 24 I (I966) I694.

7 C. J. Ballhausen, Introduction to Ligand Yield Theory, McGraw Hill, New York, 1962, p. I65.

8 P. Hemmerich, in J. Peisach, P. Aisen and W. E. Blumberg, The Biochemistry of Copper, Academic Press, New York, I966, p. I5.

9 B. Mackler, P. J. Collipp, H. M. Duncan, N. A. Rao and F. M. Huennekens, J. Biol. Chem., 237 (I962) 2968.

io H. R. Mahler, B. Mackle R, S. Grandchamp and P. P. Slonimski, Biochemistry, 3 (Ig64) 668.

I I P. P. Slonimski, La Formation des Enzymes Respiratoires chez la Levure, Masson Press, Paris, I953.

I2 T. Yamanaka, in J. Peisach, P. Aisen and W. E. Blumberg, The Biochemistry of Copper, Academic Press, New York, 1966, p. 275.

Received June 30 th, 1967

Biochim. Biophys. Acta, I43 (I967) 636-638 